\title{
Emotional Management Skill at Work Place: A Study at Government Department in Seberang Perai Tengah
}

\author{
Che Haslina Abdullah, Salina Hamed, Rafizah Kechil, and Hamzah Abdul Hamid
}

\begin{abstract}
Emotional management is the ability to maintain control when situation, people and events make excessive demands. This ability is an important mechanism for the civil servants to acknowledge emotions and recognizing coping strategies. The purpose of this study is to identify how the civil servant dealing in the emotional management at work place. This includes developing an effective model to manage emotional level at work place. The participants were 120 civil servants randomly selected from the eleven government's departments in Seberang Perai Tengah. The study adopts a quantitative method. The result indicated that the "Doa" (invocation- is an act of supplication) is the prime method in managing emotions. Another way to manage emotions is to be patient and willing to endure towards any problems encounter. These two positive actions enable to buffer the negative effects of emotional level on civil servants.
\end{abstract}

Index Terms-Civil servant, emotional management, government's department, skill.

\section{INTRODUCTION}

Emotion is a beautiful aspect of human life in which it expresses joy, love, passion, anger, frustration, hatred as well as depression. Emotions are unique to each individual and normally human beings have no trouble figuring out if someone is showing happiness, surprise, fear or anger by looking at the person's face. Positive emotions are filled with desire for enjoyment, enthusiasm, laughter and unity while negative emotions are filled by fear of the unknown, grief and regret.

A civil servant who possess positive emotion are more equipped in setting up boundaries in their lives as well as have some elements required such as self-acceptance, positive relation with others and environmental mastery. On the other hand, a civil servant who possesses negative emotion is lack of confidence in their abilities to deal with work demands. Therefore, the ability to effectively deal emotions in the workplace assists civil servants in managing occupational stress and maintaining psychological well-being. The increasing of emotional managing skills can help civil servants to deal more effectively with their feeling for successful job performance.

Manuscript received February 20, 2013; revised April 20, 2013.

This work was supported in part by the Research Management Institute (RMI), Universiti Teknologi MARA, Shah Alam, Selangor, Malaysia under Grant 600-RMI/ST/DANA 5/3/Dst (137/2011).

The authors are with the Center for Islamic Thought and Understanding (CITU), Universiti Teknologi MARA, 13500 Permatang Pauh, Pulau Pinang Malaysia (e-mail: haslina062@ppinang.uitm.edu.my, salina132@ppinang.uitm.edu.my,_rafizah025@ppinang.uitm.edu.my, hamzah4623@ppinang.uitm.edu.my).

\section{LITERATURE REVIEW}

Emotion is a product of the interaction between physiological arousal and cognitive appraisal. All human beings behavior endeavor for accomplishing a purpose either to obtain pleasure or to avoid pain. People's experience of emotion depends on what they find in their environment and on the way they appraise the events around them. Emotions can be classified into several components such as happiness, sadness, fear, anger, surprise and disgust [4].

As human beings, we all experience a wide range of emotion and sometimes human emotions can be complicated or confusing. However, it is truly important to understand and nurture our positive emotions such as joy in order to handle less pleasant emotion. People who are emotionally healthy are in control of their emotions and their behavior. They are able to handle life's challenges, build strong relationship and increase self-confidence and high self-esteem. On the other hand, unhealthy emotions are often devastating and lead to inaction, procrastination, work problems and relationship issues. According to a research study from the University of Missouri-Columbia, many employers do not want their staffs to express any type of strong emotion, positive or negative. The only proper way to manage negative emotions at work is for employees to hide their emotions while positive emotions need to be expressed in moderate level. Current research indicated that effective emotional management skill helps the managers on positive and fruitful decision-making. Letting go of negative emotions will benefit person's life in so many ways if not negative emotions can exert influence over both the thoughts and behavior and thus affect physically. Stress as body response to physical and mental demands or in other words stress is a psychological and physiological response to events that upset our personal balance in some way [8]. Stress can be the result of 'too much or too little arousal resulting in harm to mind and body' [7]. Stress in relation to personal capabilities 'a demand made on the adaptive capacities of the mind and body' [5].

Studies have shown that too much challenge, hardship or change cause an increase in the risk of illness. Experts refer to stress as the 'silent killer' since stress is a contributing factor for ailments like backaches, insomnia, cancer, chronic fatigue syndrome, heart disease or lung diseases. Human competencies like-self-awareness, self-regulation, and empathy add value to cognitive abilities in many domains of life. In addition, emotional competencies can be developed to achieve outstanding performance. Emotional competence can lead to improved health avoiding stress that would result from suppressing emotions [6]. 


\section{MethodolOGY}

\section{A. Research Type}

This study adopts a quantitative method. The descriptive analysis and Spearman-Rho Correlation was used to analyze the data. Data was gathered via a self-administered questionnaire. The tool of the study is an eight-part questionnaire in which we examined 5 areas considered important in relation to emotional management: coping strategies, self-motivational, empathy skill, social interaction, effectiveness and certain demographic variables.

\section{B. Population/Sample}

The populations of this study are all the civil servants from eleven government department in Seberang Perai Tengah, Pulau Pinang, Malaysia. The participants were 120 civil servants randomly selected from each government department. The questionnaire consisted of respondent personal and socio-demographic information.

\section{RESULT}

\section{A. Respondent Demographics}

The findings of this study show that a total of 54 demographic respondents are male and 66 are female. The average ages of the respondents in this study are from 21 to 30 years old (35\%) and from 31 to 40 years old $(27.5 \%)$. The majority of the respondents are Malays with the percentage was $79.2 \%$. There are only 19 persons are Chinese ethnic and 5 persons are Indian and other ethnic one. Level of education of civil servants working in these eleven government departments was Sijil Pelajaran Malaysia (SPM) or equivalent with $40.8 \% .99$ of them are supported staff and 21 persons under the management and professional group. The majority of them have fixed positions and retirement pension with percentage rate of $84.2 \%$.

\section{B. Emotion Management Skill}

Fig. 1 shows the percentage of the actions taken by civil servants when they were suffering from stress. It is shows that the civil servants manage their stress by prayer, patience and pleased. Table I shows the effect obtained by the actions taken. A total of $63.3 \%$ of the respondents obtained a good effect through actions taken.

As the data in this study is an ordinal scale, spearmen rho correlation analysis was used to determine the relationship between actions taken and the effect. There are two categories of actions taken, positive action and negative action.

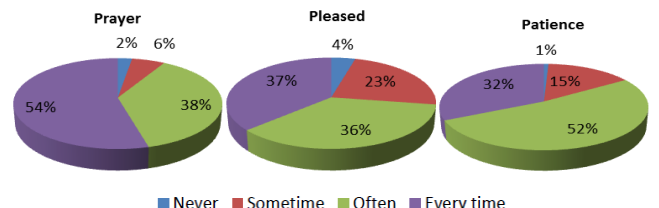

Fig. 1. Emotion management skill.

TABLE I: THE EFFECT OBTAINED BY THE ACTION TAKEN

\begin{tabular}{lcc}
\hline \hline Effects Obtained & Frequency & Percentage \\
\hline Extremely Good & 41 & 34.2 \\
Good & 76 & 63.3 \\
Unsatisfactory & 3 & 2.5 \\
\hline \hline
\end{tabular}

Table II shows the results of spearmen correlation for the relationship between positive action and the effect.

\begin{tabular}{lc} 
TABLE II: SPEARMEN CORRELATION FOR POSITIVE ACTION \\
\hline \hline Spearman correlation constant value & 0.088 \\
Value p (significance) & 0.336 \\
\hline
\end{tabular}

Table III shows the results of correlation analysis to examine the relationship between spearmen negative action and the effect.

\begin{tabular}{lc} 
TABLE III: SPEARMEN CORRELATION FOR NEGATIVE ACTION \\
\hline \hline Spearman correlation constant value & -0.090 \\
Value p (significance) & 0.330 \\
\hline \hline
\end{tabular}

From the analysis, $\mathrm{H}_{0}$ unsuccessful rejected. This shows that there is no significant relationship between the actions taken and the effect (see Table II). This means that, after the positive action is taken, the effect obtained is good. However, this relationship is too weak and not significant at 0.05 . The results are contrary to the respondents who chose to take negative action. However, the number of respondents who chose to take a negative action was very little.

\section{Motivation Skill}

Fig. 2 shows the percentage of motivation skill that taken by the civil servants in enhancing morale, while Table 4 shows the effect. Based on Table IV, 59.2\% of the respondents obtained a good effect through actions taken.

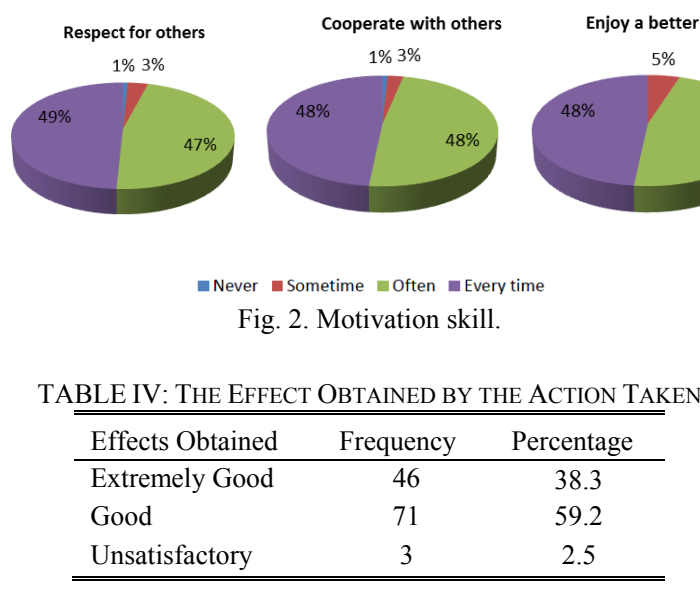

Table $\mathrm{V}$ below shows the results of spearmen correlation test to examine the actions taken to improve the spirit of working with effects arising from such action.

\begin{tabular}{l} 
TABLE V: SPEARMEN CORRELATION TEST TO EXAMINE THE ACTIONS \\
TAKEN \\
\hline \hline Spearman correlation constant value \\
Value p (significance)
\end{tabular}

The findings of the analysis show that $\mathrm{H}_{0}$ successfully rejected. This means that there is a correlation between the actions taken to improve services and the effects arising from the actions taken.

\section{Empathy Skill}

Fig. 3 shows the percentage of the empathetic of what other people think or feel. Based on Fig. 3, the majority of 
respondents felt that they often have the empathy to understand what other people think or feel.

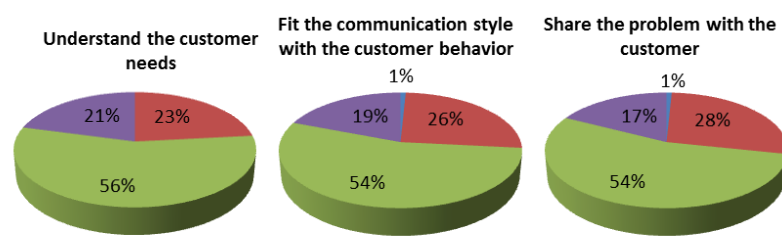

- Never $\backsim$ Sometime woften $\square$ Every time

Fig. 3. Empathy skill.

\section{E. Social Communication Skill}

Fig. 4 shows the percentage of the social relationships of the civil servants while Table VI shows the effect obtained by the action taken. Based on Table V, 50.8\% of the respondents obtained a very good effect through the actions taken.
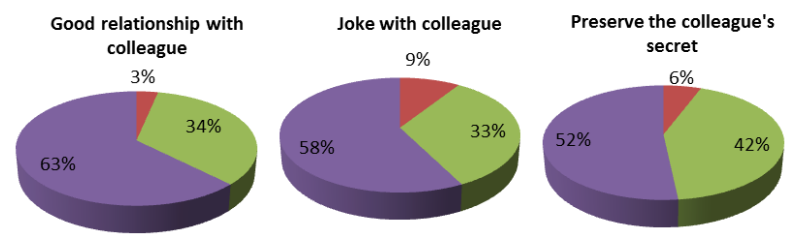

Often Every time

Fig. 4. Social communications skill

\begin{tabular}{ccc} 
TABLE VI: THE EFFECT OBTAINED BY THE ACTION TAKEN \\
\hline \hline Effects Obtained & Frequency & Percentage \\
\hline Extremely Good & 61 & 50.8 \\
Good & 58 & 48.3 \\
Unsatisfactory & 1 & 0.8 \\
\hline \hline
\end{tabular}

Table VII shows the results of spearmen correlation test to study the relationship between social relations and the impact of government personnel related actions.

\begin{tabular}{ll}
\multicolumn{2}{c}{ TABLE VII: SPEARMEN CORRELATION TEST } \\
\hline \hline Spearman correlation constant value & 0.295 \\
Value p (significance) & 0.001 \\
\hline \hline
\end{tabular}

As a result of the correlation test indicates that the test is significant at the 0.05 significance level. This means that there is a positive relationship between social relations and the impact of government personnel related actions.

\section{F. Islamic Emotionaltherapy Model}

From the result of this study, the researchers took the initiative to build a model of emotion management skills among the civil servants. This model is called the Islamic Emotionaltherapy Model (IEM). Refer to Fig. 5.

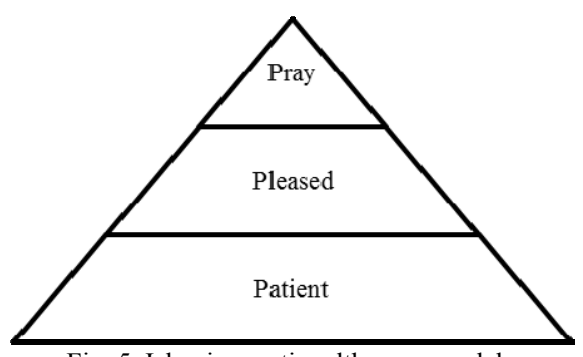

Fig. 5. Islamic emotionaltherapy model.
Praying is a very important action in managing negative emotions. If someone feels anger and sad, they can turn to God directly since prayer can help to relieve stress and bring about a more relaxed state of mind and a higher level of contentment [1]. Furthermore, prayer cultivates in man love of good for others and instructing mankind to do what is beneficial, and endeavor to fulfill humanity's objectives of progress in social construction.

The second element in the Islamic Emotionaltherapy Model is to be pleased for any distress and encounter of hardship. If the individual can accept and be pleased with the situation, then it is the real way to enlightenment which will banish stress from the life forever. Moreover, the motivational skills will be increase because the individual was willing to accept whatever the challenges were [3]. Therefore, the civil servants are able to share the problem with others and enhance communication and social relationships more intimate and friendly. On the other hand, these civil servants can be open mind when facing the indignity of others.

Patient is a very good positive attitude to be adopted, thus it becomes the third element in the Islamic Emotionaltherapy Model. Patient can form a person's personality for the better, especially when they facing the various emotional disorders. This nature should always be applied because it can make individual's soul to be kind to other people [2]. This method will further strengthen the social relationships and communication among workers.

\section{CONCLUSION}

The civil servants who are capable of managing their emotions would contribute to a positive and harmonious ambience to a workplace. Furthermore, it is important to note that these civil servants have a variety of positive attributes and tools on hand for positive socialization and in understanding both self and others.

\section{ACKNOWLEDGMENT}

We would like to express our appreciation to the Rector of UiTM Cawangan Pulau Pinang, Associate Prof. Mohd Zaki Bin Abdullah and the Coordinator of Research Management Unit, UiTM Cawangan Pulau Pinang, Dr. Mohd Fauzi Bin Ismail, for their support and help. Our acknowledgement also goes to all the office staffs of UiTM Cawangan Pulau Pinang for their cooperation.

\section{REFERENCES}

[1] A. Attas and S. M. Naquib, Prolegomena to the metaphysics of Islam, Kuala Lumpur: International Institute of Islamic Thought and Civilization, 1995, pp. 107.

[2] A. Mandili and A, Q. A. Muthalib, Penawar Bagi Hati, Johor Bahru: Perniagaan JAHABERSA, 2007. pp. 122.

[3] Al-Qarni, Aidh Abdullah Don't Be Sad. Trans, Abu Hasan Din al-Hafiz. Kuala Lumpur: Darul Fajar, 2009, pp.197

[4] P. Anathbandhu, "Creating More Effective HR Managers through emotional Intelligence Skills Training," Asian Journal of Management Intelligence, pp. 3, 2010.

[5] D. Fontana, Managing Stress, British Psychological Society \& Routledge Ltd., 1989.

[6] D. Goleman, Emotional Intelligence, 1995.

[7] W. Schafer, Stress Management For Wellness, ( $2^{\text {nd }}$. Ed), Orlando: Harcourt Brace, 1992, pp. 113. 
[8] R. D. Smither, the Pschology of Work and human Performance, (2nd. Ed), New York: Harper Collins College Publishers, 1994, pp. 104.

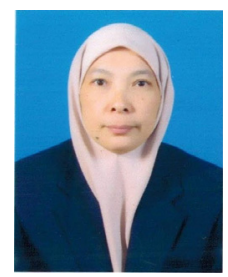

A. C. Haslina was born in Terengganu, 1963, 22nd October. Obtained her First Degree in Islamic Studies from Universiti Kebangsaan Malaysia (UKM) and Master Degree in Comparative Religion from Universiti Malaya (UM). In past, she worked at Universiti Teknologi Malaysia (UTM) at Kuala Lumpur as a contract lecturer. Currently, she is working as a SENIOR LECTURER at Universiti Teknologi Mara (UiTM) Penang. She had produced several books such as Mutiara Keluarga Bahagia which was published by UiTM Pahang (1999) dan Prinsip Asas Islam from UiTM Penang (2010). Her last research is about emotional management skill among the workers at Penang. Madam Che Haslina Abdullah did not register in any professional societies.

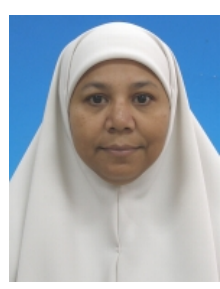

H. Salina was born in Penang, Malaysia received her B.A.(Mathematics) from Indiana University, Bloomington, Indiana, U.S.A. in year 1986. Furthering her study at Eastern Michigan University, Ypsilanti, Michigan, U.S.A. she was earned her Master's degree, in Mathematics in year 1989. In past, she was a school teacher in Penang for 13 years. Currently, she is working at Universiti Teknologi Mara (UiTM) Penang, Malaysia as a senior LECTURER and her area of interest is education and pure mathematics. Madam Salina Hamed is a members of Persatuan Sains Matematik Malaysia (PERSAMA).

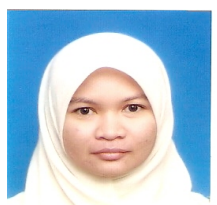

K. Rafizah was born in Penang, Malaysia, 21st January 1980) received her B.Sc. (Hons)(Applied Maths) from Universiti Sains Malaysia (USM), Penang, Selangor, Malaysia in year 2003. Furthering her study at Universiti Sains Malaysia (USM) Penang, Malaysia, she was earned her Master's degree, in Mathematics in year 2004. In past, she worked at Institut Teknologi Tinggi Kulim, Kedah, Malaysia as a lecturer. Currently, she is working at Universiti Teknologi Mara (UiTM) Penang, Malaysia as a lecturer and her area of interest is Computer Aided Geometric Design. Madam Rafizah Kechil is a members of Persatuan Sains Matematik Malaysia (PERSAMA).

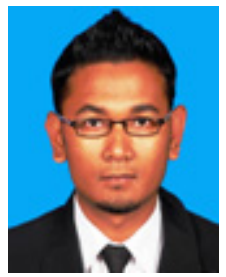

A. H. Hamzah was born in Penang, Malaysia, 1st July 1986) received his B.Sc. (Hons)(Statistics) from Universiti Teknologi Mara (UiTM) Shah Alam, Selangor, Malaysia in year 2010. Furthering his study at Universiti Sains Malaysia (USM) Penang, Malaysia, he was earned his Master's degree, also in statistics in year 2012. In past, he used to work at Penang Research Centre in Socio-economy (PReCISE) as an Assistant Researcher, while at Chief Minister of Penang Incorporated as an Assistant Manager. Currently, he is working at Universiti Teknologi Mara (UiTM) Penang, Malaysia as a lecturer and his area of interest is multivariate data analysis. Mr. Hamzah Abdul Hamid did not register in any professional societies. 